\title{
Biblijne argumenty ad absurdum świadectwem prawdziwości wiary chrześcijańskiej
}

\begin{abstract}
Argumentum ad absurdum, as a way of thinking or acting which is pointless from the point of view of rationality and predictability of a human's action, is intentionally planned in order to justify the uniqueness and thus veracity of the existence of something compared to commonly accepted standards of behaviour. The universality of these standards is questioned by introducing factors that go beyond the patterns of commonly accepted standards. In the Bible, there are also absurd situations from the point of view of human predictability which are directly attributed to God. This absurdity of God's action, in comparison to the rights guiding pagan religions and the rationally accepted human behaviour strengthens the faith in His existence. Going beyond the area of "normalcy" proves in the strongest way that these facts, which are seemingly at variance with logical thinking, are indeed true. These facts are paradoxically a strong and durable foundation of the Christian faith.
\end{abstract}

Keywords: religion - Bible - God - Christus - absurd - morality

\section{Wstęp}

Zym jest argumentum ad absurdum w kontekście przedstawianych poniżej wywodów? Nie chodzi o rodzaj argumentu w sensie logicznym, filozoficznym bądź prawniczym, lecz bardziej o sposób myślenia lub postępowania absurdalny z punktu widzenia racjonalności działania człowieka. Jest to jednak sposób celowo zamierzony, by uzasadnić prawdziwość własnego istnienia na tle powszechnie przy- 
jętych wzorców postępowania. Łatwą tego egzemplifikacją może być na przykład absurdalne z punktu widzenia logiki chodzenie podczas upalnego lata w kożuchu. Jeśli słyszę, że ktoś tak czyni, muszę za oczywisty przyjąć fakt, że on istnieje, właśnie z tej racji, że postępuje w tak dziwny sposób. Gdyby bowiem nie istniał, nie zdarzyłby się ów przypadek. Podobnie ocenić można postępowanie tysięcy męczenników chrześcijańskich, którzy dla wiary poświęcili swe życie, oddając je dobrowolnie. Przykład ów jest wartościowy nie tylko dla argumentowania za ich istnieniem, lecz - i może przede wszystkim - dla udowodnienia prawdziwości istnienia Boga, któremu swe życie ofiarowali. W przeciwnym wypadku należałoby uznać ich za niepoczytalnych psychicznie. Jakkolwiek często nie słyszelibyśmy o kimś, że postąpił nieracjonalnie, nielogicznie czy bezsensownie, nigdy nie podajemy w wątpliwość samego faktu zaistnienia czegoś, co wydaje się niemal niemożliwe do zrozumienia i uzasadnienia. Sama Biblia dostarcza wielu przykładów absurdalności ludzkiego postępowania, jak choćby kazus Abrahama, który uwierzył, że w wieku niemal 100 lat może zostać ojcem, mając w dodatku za żonę kobietę całkowicie niepłodną (Rdz 15,5-6) ${ }^{1}$, czy wiara Maryi, że zostanie Matką Jezusa, poczętego nie w wyniku zapłodnienia przez mężczyznę (Łk 1,35-38). Czy równie absurdalnie nie postępowała Penelopa, latami oczekując przybycia swego męża do domu z wyprawy wojennej, odrzucając propozycje zamążpójścia tak wielu znamienitych zalotników? Największym chyba absurdem wydaje się dobrowolna śmierć Chrystusa w straszliwej męce za własnych nieprzyjaciół (J 10,17b-18a; Rz 5,7-8). Wszystkie tego typu zachowania motywowane są siłą własnej wiary i przekonania, że nastąpi to, co z racjonalnego punktu widzenia wydaje się niemożliwe ${ }^{2}$. Znane jest ponadto zachowanie zupełnie niemieszczące się w kanonach ludzkiej przewidywalności, choć wiadomo było, że cudu nie będzie. Sławnymi wydarzeniami tego typu są obrona Termopil przez Spartan wobec nawały armii perskiej lub powstanie w getcie żydowskim w Warszawie podczas ostatniej wojny. W pierwszym czy drugim typie zachowań nikt jednak nie kwestionuje ich rzeczywistości. Więcej, absurdalny fakt, że nastąpiły, dowodzi ich prawdziwości właśnie dlatego, iż zdrowy rozsądek nakazuje po prostu zaprzestać jakichkolwiek działań w sytuacjach, gdy ludzka nadzieja jest martwa.

Także w Biblii znajdujemy przypadki działania absurdalnego na tle ludzkiej przewidywalności, które przypisane zostały wprost Bogu³. Czytelnikom dobrze

${ }^{1}$ Tekst Rz 4,17-19 ukazuje istotę wiary wykraczającej poza rozumowanie oparte wyłącznie na doświadczeniu życiowym. Naprzeciw prawom starzenia się staje siła wiary pokładanej w Bogu wszechmocnym, mogącym zawiesić prawa, które sam stworzył. Por. R.H. Mounce, Romans. An Exegetical and Theological Exposition of the Holy Scripture, New American Commentary 27, Broadman Press, Nashville 1995, ss. 128-130.

2 Przykład pozornego absurdu wiary w zderzeniu z rozumem odnaleźć można w mowie Jezusa do uczniów we fragmentach Mt 17,20 i Łk 17,6, które omawiam w dalszej części artykułu.

${ }^{3}$ Por. m.in. Wj 36,1-2; 1 Krl 3,12; 5,21; 2 Krn 2,11; Ezd 7,25; 8,18; Prz 2,6; 3,19; 21,30; Ps 19,$8 ; 107,43$. 
znana jest przypowieść Jezusa o robotnikach w winnicy, którzy niezależnie od długości czasu pracy wynagrodzeni zostali taką samą zapłatą, co wśród pracujących najdłużej zostało odebrane jako niesprawiedliwość (Mt 20,1-16). Apostoł Paweł stwierdza, że drogi Bożej mądrości najczęściej różnią się od dróg mądrości tego świata (1 Kor 1,27-29), w którego przekonaniu wydają się zupełnie absurdalne. Jezus stwierdził, że mentalność tego świata kieruje się zupełnie inną logiką niż jego Stwórca (Mt 20,25-28). Nie dziwi więc, że już na samym początku tekstu biblijnego można odnaleźć zapisy całkowicie kolidujące z logiką działania człowieka. Wszystkie, podane poniżej, funkcjonują na fundamencie wiary, na rzecz prawdziwości której przemawia owa absurdalność działania samego Boga na tle istniejących wówczas praw kierujących religiami pogańskimi (dwa pierwsze punkty) oraz akceptowane przez rozum postępowanie człowieka (punkt trzeci). Wyjście poza ów obszar „normalności” świadczy bodaj najmocniej o prawdziwości faktów i zrodzonej z nich wiary, pozornie niezgodnej z logiką myślenia.

\section{Posłanie Abrahama}

Tekst biblijny, podający to bodaj najważniejsze w życiu bohatera wydarzenie, znajduje się w Księdze Rodzaju 12,1.3, z czego dla potrzeb rozważań niniejszego opracowania najważniejszy jest paradoksalnie początek, wers 1:

Pan rzekł do Abrama:

„Wyjdź z twojej ziemi rodzinnej i z domu twego ojca do kraju, który ci ukażę.

Będę błogosławił tym, którzy ciebie błogosławić będą,

a tym, którzy tobie będą złorzeczyli, i ja będę złorzeczył.

Przez ciebie będą otrzymywały błogosławieństwo ludy całej ziemi”.

Jeśli w świetle ideologii dawnych religii starożytnego Bliskiego Wschodu kontakt między bóstwem a wierzącym w nie człowiekiem nie jest niczym szczególnym, sama treść nakazu musi zastanowić. Jest to zwłaszcza wartościowe w kontekście rozważań nad koncepcją bóstw jako władców konkretnego obszaru ziemi, pojmowanej jako całość: przestrzeń życia człowieka, lecz także świat podziemny i niebiański. Mieściły one nie tylko konkretny „adres” świątyni, czyli domu bóstwa, lecz stanowiły domenę jego władztwa. W taki właśnie sposób były pojmowane: zawsze w relacji do terytorium, którym zawiadywały. Stosunkowo dość liczne, zachowane do czasów współczesnych inskrypcje, wyraźnie wskazują na konkretny kraj, jako domenę panowania jakiegoś bóstwa, by wspomnieć choćby Egipt, jako własność faraona, a przez niego własność Amona-Re, Babilon, jako przestrzeń władania Marduka, Kanaan, pod zwierzchnictwem głównego bóstwa o imieniu El, itd. Bodaj wszystkie, znane dotąd z badań paleograficznych źródła pozabiblijne wskazują, że głównym sposobem definiowana bóstwa, jego wielkości, ważności dla swych wyznawców oraz miejsca w panteonie innych bogów, był za- 
kres i wielkość obszaru, którym ono władało . Teksty biblijne żywo odzwierciedlają ów sposób postrzegania bóstw pogańskich, wspominając o bogach konkretnych ziem i krajów 5 . Jednak z oczywistych względów nie tyle obszar i wielkość ziemi stanowiły o randze bóstwa, ile zamieszkujący ją wyznawcy, pojmowani jako wasale, nad którymi bóstwo sprawowało swą pieczę, lecz od których samo było zależne poprzez składane ku jego czci ofiary. Z tej właśnie racji myślenie mityczne doprowadzało do przekonania, że bóstwa najbardziej dbały o liczbę i jakość ofiar im składanych. Ten swoisty rodzaj usług kultycznych był nagradzany w przypadku kultu poprawnego i przynoszącego chwałę lub ganiony klęskami i nieszczęściami, w przypadku zaniedbań ${ }^{6}$.

Oprócz tych powinności bardzo ważne było permanentne rozszerzanie domeny bóstwa w postaci zwiększania terytorium jego oddziaływania, co najczęściej działo się już to poprzez wojny, już to poprzez traktaty i sojusze polityczne. Wszelkie tego typu działania przypisywano z góry bóstwom pragnącym stale powiększać sferę swego oddziaływania na ludzi. Nie można jednak pominąć faktu, że to ludzie, nie bóstwa, wykazywali się inicjatywą w tej dziedzinie7. Warto także dodać, że kult bóstw odbywał się w konkretnych miejscach, w wyznaczonych ku temu świątyniach, które specjalnie im poświęcono, i to od istnienia, a także wspaniałości domu bóstwa uzależniona była jego ranga w społeczności. Wielkość obszaru, na którym oddawano cześć bóstwom, była powiązana z oczywistych względów z liczbą zamieszkujących je wyznawców. Cóż bowiem znaczy terytorium, jeśli nie byłoby na nim czcicieli któregoś z bogów? Ich ranga i miejsce w panteonie musiały więc ściśle zależeć od liczby oddających im cześć ludzi. Część z nich bowiem, powoływana pod broń, stanowiła o sile armii, prowadzonej przez władcę, stanowiącej jednak własność danego boga, w wojnach i konfliktach między państwami i miastami starożytnego Wschodu. Utrata wyznawców, zwłaszcza w walce, kataklizmie czy zarazie, stawała się przyczyną upadku autorytetu bóstwa, skazanego coraz bardziej na zapomnienie i niebyt, zwłaszcza kultyczny.

Jeśli chodzi o relację między bóstwem a jego wyznawcą, należy podkreślić przede wszystkim właściwą rangę tych relacji obopólnie zależnych: im wyższa pozycja bóstwa w panteonie, tym wyższa ranga społeczna jego wyznawcy, i odwrotnie: autorytet społeczny wyznawcy decydował o randze bóstwa, które wyznawał. To właśnie człowiek stawał się swoistym znakiem wielkości i powagi bóstwa i dlatego najważniejsze były te, których wyznawcą był przede wszystkim władca państwa

${ }^{4}$ Szersze opracowanie tematu: D.I. Block, The Gods of the Nations: A Study in Ancient Near Eastern National Theology, Wipf et Stock, Eugene 2013, ss. 21-35.

${ }^{5}$ Por. m.in. Wj 12,12; Sdz 10,6; Joz 24,15; 2 Krn 32,19.

${ }^{6}$ Por. J.M. Sasson, Theologies, Priests and Worship in Ancient Mesopotamia, w: J.M. Sasson (red.), Civilizations of the Ancient Near East, t. 1, Charles Scribner's Sons, New York 1995, s. 1860 (1857-1871).

${ }^{7}$ Co znane jest szczególnie w przypadku wojen prowadzonych przez władców asyryjskich. Por. D.I. Block, The Gods of the Nations..., s. 87. 
lub miasta albo jego notable. Za pośrednictwem bowiem swego czciciela bóstwo rozciągało swą opiekę nad poddanym mu terytorium, dlatego zrozumiałe jest, że w przekonaniu wierzących bóstwa zabiegały o jak najwyższy status społeczny swych wyznawców. Ci z kolei świadczyli własnym autorytetem o ważności i wielkości bóstwa, którego chcieli być poddanymi. Przedstawiając bardzo generalnie, skrótowo i nieco w uproszczeniu strukturę religii mitycznych, można wyróżnić następujące cechy: politeizm będący wynikiem wielości istot ludzkich i podziału obowiązków, przynależność bóstw do świata ludzkiego (immanencja), płciowość bóstw na podobieństwo człowieka, powstawanie bóstw przez rodzenie, sposoby zachowania bóstw odzwierciedleniem postępowania ludzi, ograniczoność władzy bóstw do wyznaczonej im dziedziny, hierarchiczność bóstw, widzialność bóstw, czyli ikoniczność ich sylwetek na podobieństwo ciała ludzkiego, i wreszcie imiona bóstw nadawane przez ludzi w związku z pełnionymi przez nie funkcjami. Od razu można zauważyć, że religie te są jedynie projekcją świata ludzkiego na świat bogów: to, co występuje w relacjach międzyludzkich, dzieje się także w świecie wierzeń mitycznych. Hierarchia bóstw opierała się przede wszystkim na sile ich oddziaływania, czego widzialnym znakiem jest władca ziemski, gwarantujący pozycję wyznawanego przez siebie bóstwa, terytorium podległe władzy bóstwa oraz - co chyba najważniejsze - liczba wyznawców. W ten sposób przykładowo w panteonie mezopotamskim można wyróżnić bóstwa regionalne, ponadpaństwowe (An, Enlil, Enki, Isztar), narodowe (Marduk, Szamasz), lokalne (Utu z Larsy, Nanna z Ur), zaś najniższą rangę posiadały bóstwa rodzinne, czyli de facto duchy opiekuńcze.

Wspominając o sposobach rozszerzania wiary w bóstwa, na pierwszym miejscu zdecydowanie należy wymienić wojny i niewolnictwo, następnie dekrety królewskie oraz - rzadziej - doświadczenie dobroci bóstw. Ideologia władzy bóstwa była natomiast oparta na przekonaniu, że bogom zależy na jak największej liczbie wyznawców, pośród których władca, będący zarazem najwyższym ofiarnikiem, zajmował pierwsze miejsce. Drugim elementem było posiadanie jak największego obszaru władzy, co dokonywało się zwłaszcza poprzez wchłanianie lokalnych kultów i praktyk religijnych lub rugowanie ich poprzez uznanie wyższości wiary najeźdźców.

W świetle powyższych, skrótowych rozważań opis biblijny posiada szczególne cechy „nienormatywności” działania Boga Abrahama. Już pobieżne spojrzenie na tekst wskazuje przede wszystkim na istnienie i działanie Boga jednej rodziny, zatem zdecydowanie nienależącego do grona najważniejszych w kontekście przyjmowanego powszechnie panteonu bóstw. Całość tekstów Rdz 12-25, relacjonujących koleje losów Abrahama i jego rodziny, mówi wyłącznie o Bogu tego konkretnego rodu lub szczepu, co zostaje przedłużone na kolejne pokolenia: Izaaka, Jakuba i jego synów. Nie jest to więc Bóg z wyobrażeń mitycznych, dążący do zamanifestowania swej władzy nad światem w staraniu o uznanie Go za rządcę jakiegoś panteonu. Pośród hierarchii bóstw plasowałby się On na najniższym stopniu opie- 
kuna rodziny, stojąc niżej od bogów lokalnych, narodowych czy władców całego regionu. Ponadto Bóg ów absolutnie nie żąda uznania Go za jedynego prawdziwego, z koniecznością odrzucenia wszelkich innych bóstw. To żądanie pojawi się dopiero w I przykazaniu dekalogu (Wj 20,3), odnoszącego się do czasów Mojżesza i wędrówki Izraelitów z Egiptu do Kanaanu, oraz w znacznie późniejszych tekstach prorockich ksiąg natchnionych. Ważna jest również obserwacja, że to nie Abraham - najprawdopodobniej do tej pory zwykły wyznawca politeizmu swych przodków i swego czasu - szukał kontaktu z którymś z bóstw, lecz właśnie Bóg przejął inicjatywę objawienia siebie człowiekowi. Sam wybraniec nie jest także nikim szczególnym, zwłaszcza tak cennym dla bóstw królem czy notablem miasta, lecz tylko pasterzem, jakich wielu wówczas było, co przekonuje, że Bogu Biblii nie zależało na wielkości urzędu piastowanego przez wyznawcę.

Otóż w opowiadaniach biblijnych tam, gdzie pojawia się zwrot wajjô'mer $J H W H$, „Pan rzekł”, z nakazem uczynienia czegoś, chodzi o zmianę toku akcji ${ }^{8}$. W przypadku dotychczasowego życia Abrahama, który w międzyczasie przeniósł się z rodzinnego Ur do położonego tysiące kilometrów na północ Charanu (Rdz 11,27-31), oznacza to dokończenie planu Boga, polegającego na całkowitej przemianie sposobu życia Jego wybrańca. Najbardziej spektakularnym tego elementem jest nakaz zmiany miejsca zamieszkania, połączony z koniecznością zerwania dotychczasowych relacji rodzinnych ${ }^{9}$. Nie jest to więc zmiana miejsca zamieszkania i życia spowodowana jakimikolwiek przyczynami naturalnymi, jak prawdopodobnie w przypadku opuszczenia Ur i udania się do Charanu, co trzeba specjalnie podkreślić.

Wyraźna niespójność z przyjmowanymi w starożytności poglądami na działanie bóstw religii mitycznych ukazuje się wpierw w gotowości na utratę wyznawcy poprzez możliwość przejęcia przez niego miejscowych kultów i zwyczajów. Jest bowiem nie do pomyślenia, by wyznawca, udając się w pojedynkę lub w niewielkiej grupie swych krewnych, zachował własną wiarę w całkowicie sobie obcym środowisku religijnym, jeśli nie miałby wsparcia w permanentnej obecności bóstwa, w które wierzy. Jest to niemożliwe choćby z faktu niemożności pokojowej koegzystencji wierzeń tak całkowicie rozbieżnych, jak wiara w istnienie wielu bogów oraz Boga jedynego, widzianego tylko jako duch opiekuńczy rodu ${ }^{10}$. W tekście widoczny jest również całkowity brak powodu uzasadniającego opuszczenie ziemi

${ }^{8}$ Por. np. Rdz 1,3.29; 2,18; 6,13; 7,1; 31,3; Wj 3,7; 4,19.27; 6,1; 7,26; 8,1.12; 9,8.22; 10,12.21; 11,1; Lb 3,40; 11,16; 12,4 itd.

${ }^{9}$ Zerwanie to nie posiada oczywiście charakteru absolutnego, o czym świadczy późniejsza wola Abrahama, by jego sługa szukał żony dla Izaaka pośród krewnych (Rdz 24,2-4) oraz służba Jakuba u jego wuja (Rdz 29-32). Jednakże rygorystyczny zakaz Rdz 24,8 powrotu do ziemi, którą opuścił, świadczy o nieodwracalności biegu życia bohatera opowiadania biblijnego, zgodnie z wolą Boga.

${ }^{10}$ Przykład Amenhotepa IV, usiłującego w Egipcie wprowadzić wiarę w Atona, jedno bóstwo tarczy słonecznej, spotkał się z ostrą reakcją kleru i ostateczną klęską reformy religijnej 
rodzinnej i kultu przodków. Także motyw nakazu nie jest typowy dla religii pogańskiej, ponieważ brakuje w nim zamiaru zdobywania nowego terenu i wyznawców. Widoczna jest za to otwartość Boga na obcych i gotowość błogosławienia poganom ze względu na Abrahama. Wniosek, jaki wywieść można z powyższej pobieżnej tylko analizy, jest jednoznaczny: w świetle kryteriów religii pogańskich działanie Boga jest całkowicie nieracjonalne. Ponieważ jednak nastąpiło, Bóg ten musi być Bogiem prawdziwym, a nie wymyślonym przez ludzi.

\section{Anikoniczność Boga Biblii}

Dla zrozumienia wyjątkowości drugiego z przytoczonych w Biblii przykładów trzeba przypomnieć istotę funkcjonowania religii mitycznych w sferze dostrzegalności wszelkiego typu podobizn bóstw, czynionych przez człowieka. Jest to fundamentalna różnica w tym, co po wielobóstwie stanowiło najbardziej charakterystyczną cechę tychże religii ${ }^{11}$.

Jaki był nadrzędny cel tego uwidaczniania bóstw? Otóż jakikolwiek materialny wizerunek wyobrażanej sobie przez człowieka mocy nadprzyrodzonej stawał się przede wszystkim manifestacją obecności samego bóstwa pośród wierzących. Poprzez dokonywane odpowiednie rytuały, najczęściej magiczne, taki wizerunek, zwłaszcza posąg, został napełniony taką obecnością, stając się prawdziwie bóstwem, pojmowanym jako dar świata nadnaturalnego dla wierzącej społeczności. W ów przedmiot dane bóstwo po prostu się wcielało, co z jednej strony dawało ludziom możność oglądania go, zaś bóstwu - możność ingerowania w życie swych wyznawców, jak i - szerzej - w codzienność funkcjonowania świata. Elementem religii mitycznych było przekonanie o niezależnym istnieniu bóstw, lecz dopiero poprzez swe posągi i statuy stawały się one dostępne dla ludzi ${ }^{12}$. Ich fizyczna obecność warunkowała sposób działania w podległym im obszarze geograficznym, co objawiało się określonym sposobem sprawowania władzy nad wydzieloną im ziemią.

Dany wizerunek bóstwa był ponadto sposobem jego kontaktu z wierzącymi, przez co mogło być ono dostępne w aktach kultu i oddawanej im czci. Kult ten uwidaczniał się przede wszystkim w codziennej pielęgnacji posągu bóstwa oraz podawaniu mu określonej porcji żywności, by mogło ono zaspokoić naturalne

po śmierci władcy. Por. J.K. Hoffmeier, Akhenaten and the Origins of Monotheism, Oxford University Press, Oxford 2015, ss. 165-192.

${ }^{11}$ Szerzej na ten temat por. esej K. van der Toorna, The iconic Book: Analogies between the Babylonian Cult of images and the Veneration of the Torah, w: K. ven der Toorn (red.), The Image and the Book: Iconic Cults, Aniconism, and the Rise of Book Religion in Israel and the Ancient near East, Peeters, Leuven 1997, ss. 229-248.

${ }_{12}$ Por. E. Hornung, Jeden czy wielu? Koncepcja Boga w starożytnym Egipcie, tłum. A. Niwiński, Wydawnictwo Naukowe PWN, Warszawa 1991, s. 119. 
pragnienie jedzenia na podobieństwo ludzi ${ }^{13}$. W każdej świątyni rozwinął się cały rytuał ofiar składanych posągom bóstw w wierze, iż dokonywały one ich spożycia po prostu patrząc na nie. Wymagało to w oczywisty sposób zaangażowania całego personelu świątynnego ${ }^{14}$. Na koniec tej części szkicu historycznego należy zauważyć, że posąg lub malowidło bóstwa wyrażało ludzkie pragnienia kontaktu z bóstwem. W swej formie widzialnej stawało się ono bardziej dostępne, jakby bliższe odczuciom wyznawców, co z kolei mocno zacieśniało więzi między poddanymi a danym boskim władcą ${ }^{15}$.

Na tym tle wyjątkowo wręcz musi zabrzmieć kategoryczne żądanie Boga Izraela, wyrażone w tekście Wj 20,4-5a:

Nie będziesz czynił żadnej rzeźby ani żadnego obrazu tego,

co jest na niebie wysoko, ani tego, co jest na ziemi nisko,

ani tego, co jest w wodach pod ziemią!

Nie będziesz oddawał im pokłonu i nie będziesz im służył...

Przyglądając się tylko pobieżnie powyższej wzmiance biblijnej, można zauważyć, że jest to zakaz o charakterze absolutnym, funkcjonujący zarówno w sferze wiary, jak i kultu, czyli publicznego oddawania czci Bogu. Treść zakazu obejmuje wszelkie widzialne przedmioty, rzeczy, ludzi i zwierzęta. Pierwszym jego celem jest niewyobrażanie sobie Boga w jakiejkolwiek widzialnej postaci, a celem drugim - nienadawanie stworzeniom jakichkolwiek cech przynależnych Bogu. Poprzez ów zakaz Bóg Izraela przede wszystkim nie chce poddawać się jakiemukolwiek sposobowi ludzkiego przyzwania Go dla potrzeb człowieka poprzez wszelkie rytuały zaklęć czy inkantacji. Nigdy i w niczym człowiek nie może zmusić Boga do stawiania się przed nim czy na jego żądanie poprzez pośrednictwo posągu lub statuy, pojmowanych jako swoisty kanał przesyłający jakikolwiek aspekt swej boskości dla potrzeb wyznawcy i odwrotnie - nigdy człowiek nie może mieć pewności, że jakiekolwiek jego modły lub zaklęcia zostaną w pełni i niezawodnie przyjęte przez bóstwo, przed którego wizerunkiem właśnie stawał ${ }^{16}$. Jeśli, dalej,

${ }^{13}$ Tekst Dn 14,1-6 ukazuje w sposób właściwy, choć szyderczy, tym niemniej prawdziwy, mentalność starożytnych. Jedna z inskrypcji babilońskich stwierdza, że Nabuchodonozor ofiarował Mardukowi ,jednego dnia wołu [...], ryby, ptactwo, przyprawy korzenne [...], miód, twaróg, mleko, najlepszą oliwę, słodkie wino [...], w takiej ilości, jak wody w rzece, bez miary do kielichów Marduka”. C.A. Moore, Daniel, Esther and Jeremiah: The Additions. A New Translation with Introduction and Commentary, The Anchor Bible 44, Harvard University Press, New Heaven - London 2010, s. 134.

${ }^{14}$ Por. A.L. Oppenheim, Ancient Mesopotamia: Portrait of a Dead Civilization, University of Chicago Press, Chicago - London 1977, ss. 188-192.

${ }^{15}$ Por. T. Stanek, Jahwe a bogowie ludów. Idee religijne wczesnego Izraela na tle wierzeń ludów Egiptu, Mezopotamii i Kanaanu, Biblioteka Pomocy Naukowych 23, Redakcja Wydawnictw Wydziału Teologicznego UAM, Poznań 2002, ss. 81-82.

16 Takie rytuały inkantacyjne, zwane mrs pi („otwarcie ust”), dawały przekonanie o manifestacji boskiej obecności poprzez nieożywiony jej wizerunek. Por. C. Walker, M.B. Dick, The 
powszechnie wyrażano przekonanie, że posąg żywił się tym, co wyznawcy dostarczyli bóstwu, w zależności od starań czcicieli, mogło ono wyrazić swą łaskawość lub - odwrotnie - gniew w przypadku zaniedbań lub niestaranności w zabezpieczaniu jego potrzeb. Bogowie - mogąc czynić wszystko, co zechcą - stawali się w ten sposób całkowicie zależni od działań człowieka, oczekującego od nich łaskawości i spełnienia pragnień właśnie w zamian za dostarczane przysmaki. Owa pewność co do łaskawości bóstwa wyrażała się w obfitości pożywienia albo obronie przed głodem, wojną czy zarazą. Doskonałym odpowiednikiem biblijnym tego myślenia jest Ps 50,9-13, gdzie Bóg wypomina swemu ludowi traktowanie Go na modłę pogańskich idoli z przekonaniem, że potrzebuje On jakichkolwiek ofiar dla wyżywienia samego siebie. Nawet gdyby była to prawda, Bóg nie zwracałby się do ludzi o łaskę przygotowania Mu posiłku, gdyż wszystko, co jest na świecie, do Niego należy i sam wybrałby sobie coś, co odpowiada Mu najbardziej (w. 10-12) ${ }^{17}$. Wagi specjalnej nabiera stwierdzenie, że - poza doświadczeniem Izraela, jako absolutnego wyjątku pośród wszystkich bardziej rozwiniętych i wyżej zorganizowanych państw starożytnego Bliskiego Wschodu - wszędzie, gdzie to możliwe i o każdej porze panował jednolity sposób oddawania czci bóstwom, co czyniło te praktyki powszechnie akceptowalne. Dodać do tego należy, że wiele państw o religiach mitycznych prosperowało znakomicie pod względem ekonomicznym, co dawało kolejne podstawy do szerzenia kultów zwłaszcza bóstw płodności i urodzaju ${ }^{18}$. Wyjątkowość Izraela pod tym względem stawiała religię narodu nie tylko na antypodach pogaństwa, lecz znacznie trudniejszą do praktykowania, ponieważ nikt tak nie czynił. Znacznie większe stawało się niebezpieczeństwo przejścia na drugą stronę niż nawrócenia kogokolwiek z pogan.

Częstotliwość i obfitość składanych darów stanowiła jedyny, dostrzegalny wymóg bóstwa wobec wiernego wyznawcy. W religiach mitycznych zredukowano do minimum wagę zachowania etycznego, za to najbardziej liczyło się zabezpieczenie posiłków rytualnych. Oczywiście, bóstwa w jakiś sposób reagowały na postępowanie swych wyznawców, lecz w zasadzie tylko wówczas, gdy jeden człowiek czynił coś niegodziwego drugiemu, co tamtemu przeszkadzało w sposób godny czcić swego boga. Krzywda wyrządzona jednemu przez drugiego sprawiała

Induction of the Cult Image in Ancient Mesopotamia: The Mesopotamian mrs pi Ritual, w: M.B. Dick (red.), Born in Heaven, Made on Earth: The Making of the Cult Image in the Ancient Near Eeast, Eisenbrauns, Winona Lake 1999, ss. 55-121.

${ }^{17}$ Widać w tym oskarżeniu fakt uświadamiania człowiekowi całkowitej niezależności Boga od Jego czciciela. Por. J. Goldingay, Psalms. Vol. 2: Psalms 42-89, Baker Commentary of the Old Testament: Wisdom and Psalms, Grand Rapids 2007, ss. 115-116. Por. także m.in. Ps 8,6-8; 24,1-2; 104,24-25; 145,15-16; 1 Krn 29,14-16; Hi 38,41; 39,13-18,26-30; 40,15-24. Takie przekonanie sprzeciwia się ówczesnemu patrzeniu na relację bóstwo - człowiek.

${ }^{18}$ Szersze omówienie tematyki: E. Anati, The Question of Fertility Cults, w: A. Bonanno (red.), Archaeology and Fertility Cult in the Ancient Mediterranean, Papers Presented at the first International Conference on Archaeology of the Ancient Mediterranean, University of Malta, 2-5 September 1985, B.R. Grüner Publishing Company, Amsterdam 1986, ss. 2-15. 
bowiem, że na jakiś czas był on wyłączony ze składania ofiar swemu bóstwu, co umniejszało jego chwałę pośród ludu. Stąd interwencje bóstw sprowadzały się do karania winowajców w celu przywrócenia właściwego porządku kultycznego. Całkiem odwrotnie działo się we wspólnocie Izraela. Najważniejszym zobowiązaniem ludu była całkowita i bezwzględna wierność nakazom otrzymanym przez Mojżesza na Synaju w trakcie zawierania przymierza z Bogiem (Wj 24,7), nie zaś poprawność sprawowanego kultu ${ }^{19}$. Jest to tak ważne, że Bóg z definicji odrzuca ofiary Mu składane, jeśli nie są podparte wynikającym z przymierza nakazom²0.

Znaczenie żądania Wj 20,4-5a zostaje podkreślone równie bezwzględnymi nakazami niszczenia wszelkich przejawów kultu idolatrycznego w Kanaanie, ziemi zamieszkania Izraelitów. Teksty Pwt 7,5 oraz 12,2 używają czasowników totalnego zniszczenia w sekwencji: zburzycie - połamiecie - wytniecie - spalicie w odniesieniu do istniejących form kultu pogańskiego ${ }^{21}$. Dlaczego tak drastyczne żądania? Otóż owe wszędobylskie formy i miejsca kultu oznaczały możliwość składania ofiar bożkom w jakimkolwiek odpowiednim miejscu, o jakiejkolwiek porze i z jakiegokolwiek pożywienia. W takiej sytuacji wyłącznie człowiek decydował, gdzie, jak i co miało spożywać bóstwo, całkowicie uzależnione od woli i pragnień swego wyznawcy. W tym świetle specjalnego znaczenia w religijności izraelskiej nabiera nakaz centralizacji kultu oraz szczegółowe przepisy dotyczące dni, sposobu i rodzaju składanych ofiar, by wszystko opierało się na woli Boga, nie człowieka ${ }^{22}$.

Kolejnym argumentem za koniecznością wprowadzenia zapisu Wj 20,4-5a jest fakt, że w panteonie wielu bóstw religii mitycznych podzielność ról, jakie

${ }^{19}$ Por. D.K. Stuart, Exodus. An Exegetical and Theological Exposition of Holy Scripture, New American Commentary 2, Broadman Press, Nashville 2006, s. 481. Podobne żądania zawarte są również m.in. w: Wj 15,26; 19,5; Kpł 26,3-12; Pwt 5,29.33; 6,3; 11,27; 13,4; 30,2.8.20; Jr 7,23-34 itd.

${ }^{20}$ Pierwszym takim zapisem jest Rdz 4,3-5 z uzasadnieniem w wersach 6-7 akcentujących konieczność odcięcia się od zła moralnego jako warunku przyjęcia ofiary człowieka. Por. J. Lemański, Księga Rodzaju, rozdziały 1-11. Wstęp - przekład z oryginału - komentarz, Nowy Komentarz Biblijny: Stary Testament, t. I/1, Edycja Świętego Pawła, Częstochowa 2013, ss. 280-282. Dwa teksty ksiąg prorockich należy wymienić jako szczytowy atak Boga na odłączenie kultu od moralności: Iz 1,11-17 i Am 5,21-27. Oba kierują się przeciw hipokryzji kultu Izraela czasów królewskich. Por. T. Brzegowy, Księga Izajasza. Rozdziały 1-12, Nowy Komentarz Biblijny: Stary Testament 22/1, Edycja Świętego Pawła, Częstochowa 2010, ss. 160-172; D. Stuart, Hosea - Jonah, Word Biblical Commentary 31, Word Books Publisher, Dallas 1987, ss. 354-356.

${ }^{21} \mathrm{~W}$ relacji do czterech podstawowych form kultu pogańskiego: ołtarzy - steli - aszer posągów por. D.L. Christensen, Deuteronomy 1:1 - 21:9, Word Biblical Commentary 6A, Word Books Publisher, Dallas 2001, ss. 156-157.

${ }^{22}$ W Biblii zwrotem technicznym na opis nakazu centralizacji kultu jest deuteronomistyczna konstrukcja „w miejscu, które obierze sobie Pan” (Pwt 12,14.18.26; 14,23-25; 15,20; 16,2.67.11.15-16; 17,8.10; 26,2; 31,11). Por. B. Halpern, The Centralization Formula in Deuteronomy, VT 31 (1981), ss. 35-37; E. Reuter, Kultzentralisation: Entstehung und Theologie von Dtn 12, Athenäums Monografien, Bonner Biblische Beiträge 87, Anton Hain, Bonn 1993, ss. 100-105. 
wyznaczyli im ludzie, była czymś zupełnie logicznym. Bóstwa nie wchodziły sobie w kompetencje, choć ściśle pilnowały zasięgu swej władzy. W takim razie najbardziej pragmatycznym wyrazem owej podzielności ról były właśnie rzeźby i malowidła wyrażające tę czy inną umiejętność lub zadania pełnione przez bóstwa. Odwracając jednak kierunek tej myśli, trzeba stwierdzić, że nic tak jak wizerunki nie ograniczało potęgi bóstw, nie pozwalając im na bycie wszechmocnymi. Władza jednego ograniczała przecież władzę drugiego! Właśnie z tego powodu Bóg Izraela, jedyny i wszechmocny, nie mógł pozwolić na wtłoczenie Go w jakąś formę ograniczającą Jego możliwości panowania nad całym światem i rządzenia nim według własnej woli. Z tego właśnie powodu tak jasny wydźwięk posiadają wersety Pwt 4,35-38, w myśl których Izraelici mieli uwierzyć w jedynego Boga działającego poprzez konkretne wydarzenia historii ludu ${ }^{23}$.

Bóg ten jednak w zakazie tworzenia jakichkolwiek wizerunków całkowicie wyrywa się spod władzy ludzkich zmysłów, co czyniono w świecie religii mitycznych. Świadczy o tym zapis 1 Krl 19,18 wspominający o całowaniu posągu pogańskiego bożka Baala lub werset Ez 8,10 ukazujący zadowolenie ludzkich oczu na widok różnorakich zwierząt, których malowidła powstawały dla uczczenia konkretnych bóstw poprzez estetykę i artyzm wykonania. Także w tym względzie zakaz Boga Izraela stanowi konkretną trudność dla izraelskich wyznawców ${ }^{24}$.

Że zakaz czynienia podobizn Boga nie był inwencją człowieka, świadczy na koniec decydujący argument o permanentnym odchodzeniu Izraelitów od wierności zapisom prawa mojżeszowego. Passus 2 Krl 17, 6-12, jako jeden z wielu, przekonuje o karygodnej zatwardziałości ludu wobec wierności swemu Bogu ${ }^{25}$. Powyższe obserwacje pozwalają sformułować przekonanie, że prezentowany zakaz Wj 20,4-5a zupełnie wywraca dotychczasowe fundamenty religii pogańskich, zaś cała historia Izraela to pasmo niewierności temu zakazowi i próby powracania do cech religii pogańskich. Stąd uprawniony jest wniosek, iż żądanie Boga wobec Izraelitów jest absurdalne z punktu widzenia ówczesnych przekonań religijnych. Dlatego właśnie zawartość zakazu czynienia wizerunków i podobizn Boga lub bożków nie może być uznana jako wymysł człowieka, lecz jako treść podana z zewnątrz, przez samego Boga.

${ }^{23}$ Por. E.H. Merrill, Deuteronomy. An Exegetical and Theological Exposition of Holy Scripture, New American Commentary 5, Broadman Press, Nashville 1994, ss. 131-132. Nurt prorocki reprezentuje w tym względzie tzw. Deuteroizajasz, por. Iz 45,5-6.14.18.21; 46,9 oraz Dn 3,96; Jl 2,27.

${ }^{24}$ Czego z kolei dowodem jest uczynienie posągu złotego cielca pod Synajem w tym samym momencie, w którym Mojżesz otrzymywał tablice dekalogu z zakazem czynienia wizerunków idoli pogańskich. Por. W.H.C. Propp, Exodus 19-40. A New Translation with Introduction and Commentary, The Anchor Bible 2A, Doubleday, New York i in. 2006, ss. 547-554.

${ }^{25}$ Por. także m.in. Pwt 31,16-17.29; 32,15-52; Joz 23,16; Sdz 2,14-17; 2 Krn 36,14-16; Ne 9,26; Ps 106,35-41; Ez 23,2-16; Oz 4,1-3; 8,5-14. 


\section{Maksymalistyczne zachęty Jezusa z Nazaretu}

W Nowym Testamencie można odnaleźć równie zastanawiające przykłady absurdalności postępowania Jezusa z Nazaretu w świetle ludzkiej oceny moralności uważanej za „standardową” nawet w świetle prawa starotestamentowego. Najbardziej jaskrawym tego przykładem jest odpowiedź Jezusa na żądania przeciwników, by opowiedział się za wiernością przepisom prawa, lecz przeciw życiu ludzkiemu w J 8,3-8, w relacji do Kpł 20,10; Pwt 22,21-24 oraz Ez 16,38-40. Tym bardziej szokują poniższe zapisy, mogące wywołać wrażenie całkowitego absurdu w zestawieniu ze zwykłym odczuciem moralności obowiązującej w świecie współczesnym. Pierwszym z nich jest cytat Mt 5,39-40:

Jeśli cię kto uderzy w prawy policzek, nadstaw mu i drugi!

Temu, kto chce prawować się z tobą i wziąć twoją szatę, odstąp i płaszcz!

Kontekst tej wypowiedzi Jezusa to wersy 38-42 funkcjonujące w obrębie starożytnego ius talionis, którego fundamentem jest zasada „oko za oko” (Wj 21,24-25; Kpł 24,20; Pwt 19,21) ${ }^{26}$. Nauczyciel z Nazaretu uczy, że wspaniałomyślność chrześcijańska powinna wznieść się wyżej nawet od rozumowo uzasadnionego principium postępowania człowieka, pozwalającego oddać tym samym za uczynione zło w ramach sprawiedliwego odwetu ${ }^{27}$. Oddanie złem za zło mnoży tylko zło i usprawiedliwia atakującego w działaniu przeciw jego ofierze. Odwrotnie, zachowanie spokoju przecina nakręcającą się spiralę zła, pozostawiając krzywdziciela w świadomości uczynionego zła, mając nadzieję na jego poprawę. Ofiara zaś kształci swój charakter ku umiejętności przebaczenia i walki bardziej z sobą niż z przeciwnikiem. Tymczasem każdy czytelnik powyższych uwag znajdzie natychmiast cały zasób kontrargumentów, mając w świadomości możliwość rozzuchwalenia winowajcy, który nie spotyka oporu na drodze swego działania ${ }^{28}$. Do czasów współczesnych słowa Jezusa wywołują całkiem uzasadnione kontrowersje i raczej odrzucenie niż aprobatę.

${ }^{26}$ Zasada ius talionis obecna jest w prawodawstwie starożytnego Bliskiego Wschodu, zwłaszcza kodeksie Hammurabiego czy kodeksie z Esznunny. Por. T. Frymer-Kensky, Tit for Tat: The Principle of Equal Retribution in Near Eastern and Biblical Law, The Biblical Archaeologist 43/4/1980, ss. 230-234; B.S. Jackson, Problem of Exod 21:22-25 (Ius Talionis), Vetus Testamentum 23/1973, ss. 273-304; H.-W. Jüngling, Auge für Auge, Zahn für Zahn: Bemerkungen zu Sinn und Geltung der alttestamentlichen Talionsformeln, Theologie und Philosophie 59/1/1984, ss. $1-38$.

${ }^{27}$ Nawet o czasach współczesnych Jezusowi wyznawców judaizmu było to nauczanie szokujące. Por. serię artykułów w: W.M. Swartley (red.), The Love of Enemy and Nonretaliation in the New Testament, Westminster/John Knox Press, Louisville 1992.

${ }^{28}$ Por. C.L. Blomberg, Matthew. An Exegetical and Theological Exposition of Holy Scripture, New American Commentary 22, Broadman Press, Nashville 1992, ss. 113-114. 
Drugim przykładem jest nieodległy, a równie absurdalny z punktu widzenia ludzkiej oceny passus Mt 5,44:

Miłujcie waszych nieprzyjaciół

i módlcie się za tych, którzy was prześladują.

W otoczeniu wersów 43-47 widnieje odwołanie do tekstu Kpł 19,18 wspominającego nakaz miłości bliźniego, ograniczony jednak do przedstawicieli tej samej wiary, czyli do żydów, z wyłączeniem pogan, dla których rezerwowana była daleko idąca wstrzemięźliwość nie tylko uczuć, lecz także postaw ${ }^{29}$. Zatem najprawdopodobniej w najbliższym wersie 42 nie chodzi o nienawiść w ścisłym tego słowa znaczeniu, lecz o nieokazywanie miłości w taki sposób, jak czyni się to wobec najbliższych lub rodaków ${ }^{30}$. Jezus nakazuje całkowitą antytezę tej postawy w postaci miłości skierowanej ku nieprzyjaciołom i ludziom źle czyniącym, tak jak czyni się to wobec ludzi życzliwych sobie oraz przyjaciół i to na poziomie zarówno osobistym, jak i społecznym. Trzeba zaakcentować przede wszystkim postawę miłości wyrażającej się nie w odczuciach, sentymentalizmie czy wzniosłych pragnieniach, lecz konkretnym czynieniu dobra, życzliwości, przede wszystkim w modlitwie za nich (w. 44b), pozdrawianiu obcych sobie ludzi (w. 47) oraz życzeniu wszystkiego, co służy ich autentycznemu dobru ${ }^{31}$. Takie postępowanie oznacza na pierwszym miejscu walkę z własnymi ograniczeniami, słabościami i akceptacją trudnych bliźnich wbrew własnemu, ludzkiemu odczuciu. Forma żądania oznacza więc, że nie pochodzi ono od człowieka, lecz zostaje chrześcijanom narzucone przez autorytet wyższy.

Trzecim wreszcie exemplum jest perykopa Łk 17,4:

Jeśliby brat twój siedem razy na dzień zawinił przeciw tobie

i siedem razy zwróciłby się do ciebie, mówiąc: „Żałuję tego”, przebacz mu!

Prezentowane wersety nakazują powielanie we własnym życiu tego, co wielokrotnie czyni Bóg wobec grzeszników, którzy zaciągają dług winy wobec bliź-

${ }^{29}$ Nakazu nienawiści nieprzyjaciół nie ma ściśle w Starym Testamencie. Stąd chodzi o interferencję tekstów prawniczych: Pwt 23,3-6; 25,17-19 lub Ps 139,21, zawierających ów temat. Szerszy kontekst mówi o poganach, wobec których należy postępować radykalnie nieprzychylnie ze względu na niebezpieczeństwo ich przekonań dla wiary Izraela. Por. C.L. Blomberg, Matthew. An Exegetical and Theological Exposition..., ss. 114-115.

${ }^{30}$ Takie właśnie znaczenie przyjmuje też czasownik miseō („nienawidzę”) w odniesieniu do rodziców w Łk 14,26, co byłoby całkowicie szokujące zwłaszcza jako nakaz Jezusa skierowany do uczniów. Egzegeci zauważają biegunowość mentalności hebrajskiej, nie zaś znane Europejczykom stopniowanie uczuć. Por. F. Mickiewicz, Ewangelia według Świętego Łukasza, rozdziały 12-24, Nowy Komentarz Biblijny: Nowy Testament, t. III/2, Edycja Świętego Pawła, Częstochowa 2012, ss. 139-140.

${ }^{31}$ Por. A. Paciorek, Ewangelia według świętego Mateusza. Wstęp - przekład z oryginału - komentarz, Nowy Komentarz Biblijny: Nowy Testament, t. I/1, Edycja Świętego Pawła, Częstochowa 2008, ss. 250-251. 
nich, a tym samym wobec Niego, gdyż utożsamia się On zawsze z krzywdzonymi jakimkolwiek niegodziwym postępowaniem. Bóg jednak w pełni rozumie słabość ludzką i wielokrotność popadania w grzech nawet po zyskaniu Jego przebaczenia. Liczba „siedem” jest tu symbolem wielokrotności zdarzenia, jakie następuje. W ten sposób chce Jezus przypomnieć, że nikomu nie wolno potępić kogokolwiek i zabronić mu prawa do nawrócenia. Przeciwnie, ktoś ciągle i szczerze powracający z drogi grzechu może zasłużyć na miano wiernego ucznia Pana ${ }^{32}$.

Jaki jest wspólny mianownik powyższych tekstów ewangelijnych? Otóż sprzeciwiają się one fundamentalnej zasadzie sprawiedliwości wymiennej, znanej jako zasada „oko za oko”. Zachęcają do przekraczania ludzkich możliwości definiujących zachowanie „normalne”, czyli zwłaszcza prawa do obrony koniecznej i ochrony dobytku, prawa do niewspomagania wrogów oraz prawa do ograniczonej wiary w szczerość intencji winowajcy.

Sens takich wypowiedzi Jezusa zawiera się w Jego niezgodzie na bierność wobec zła i przyzwolenie na jego czynienie, na godzenie się na lenistwo lub wygodnictwo drugiego człowieka, na zniżanie się do poziomu atakującego lub nienawidzącego i nieoddawanie złem za zło, sankcjonując jego zły czyn, a wreszcie na egoistyczne ocenianie bliźniego według własnych kryteriów. Oznacza ponadto możliwość ukazania innej drogi postępowania niż droga odwetu i zemsty, dania drugiemu możliwości, jakiej pragnąłbym dla siebie, gdybym znalazł się w jego położeniu, rezygnacji z własnych roszczeń do naprawienia wyrządzonych szkód, naśladowania samego Boga w Jego wspaniałomyślności wobec winnego człowieka. Powyższe krótkie uwagi pozwalają sformułować wniosek generalny, że bez odwołania do wiary w Boga koszty takich postaw są dla człowieka zbyt wielkie, a sama postawa z czysto ludzkiego punktu widzenia tchnie wprost absurdalnością.

\section{Literatura}

Anati E., The Question of Fertility Cults, w: Archaeology and Fertility Cult in the Ancient Mediterranean, Papers Presented at the first International Conference on Archaeology of the Ancient Mediterranean, University of Malta, 2-5 September 1985, A. Bonanno (red.), B.R. Grüner Publishing Company, Amsterdam 1986.

Block D.I., The Gods of the Nations: A Study in Ancient Near Eastern National Theology, Wipf et Stock, Eugene 2013.

Blomberg C.L., Matthew. An Exegetical and Theological Exposition of Holy Scripture, New American Commentary 22, Broadman Press, Nashville 1992.

32 By dalej kroczyć drogą prawości. Liczy się jednak zawsze szczerość postanowienia i wówczas ów nakaz obowiązuje, co Jezus zaznacza w użyciu czasu przyszłego mającego właśnie sens polecenia. Por. R.H. Stein, Luke. An Exegetical and Theological Exposition of Holy Scripture, New American Commentary 24, Broadman Press, Nashville 1992, s. 430. 
Brzegowy T., Księga Izajasza. Rozdziały 1-12, Nowy Komentarz Biblijny: Stary Testament 22/1, Edycja Świętego Pawła, Częstochowa 2010.

Christensen D.L., Deuteronomy 1:1 - 21:9, Word Biblical Commentary 6A, Word Books Publisher, Dallas 2001.

Frymer-Kensky T., Tit for Tat: The Principle of Equal Retribution in Near Eastern and Biblical Law, „The Biblical Archaeologist” 4(43)/1980.

Goldingay J., Psalms. Vol. 2: Psalms 42-89, Baker Commentary of the Old Testament: Wisdom and Psalms, Baker Academic, Grand Rapids 2007.

Halpern B., The Centralization Formula in Deuteronomy, Vetus Testamentum 31/1981.

Hoffmeier J.K., Akhenaten and the Origins of Monotheism, Oxford University Press, Oxford 2015.

Hornung E., Jeden czy wielu? Koncepcja Boga w starożytnym Egipcie, tłum. A. Niwiński, Wydawnictwo Naukowe PWN, Warszawa 1991.

Jackson B.S., Problem of Exod 21:22-25 (Ius Talionis), Vetus Testamentum 23/1973.

Jüngling H.-W., Auge für Auge, Zahn für Zahn: Bemerkungen zu Sinn und Geltung der alttestamentlichen Talionsformeln, Theologie und Philosophie 59/1/1984.

Lemański J., Księga Rodzaju, rozdziały 1-11. Wstęp - przekład z oryginału - komentarz, Nowy Komentarz Biblijny: Stary Testament, t. I/1, Edycja Świętego Pawła, Częstochowa 2013.

Merrill E.H., Deuteronomy. An Exegetical and Theological Exposition of Holy Scripture, New American Commentary 5, Broadman Press, Nashville 1994.

Mickiewicz F., Ewangelia według Świętego Łukasza, rozdziały 12-24, Nowy Komentarz Biblijny: Nowy Testament, t. III/2, Edycja Świętego Pawła, Częstochowa 2012.

Moore C.A., Daniel, Esther and Jeremiah: The Additions. A New Translation with Introduction and Commentary, The Anchor Bible 44, Harvard University Press, New Heaven - London 2010.

Mounce R.H., Romans. An Exegetical and Theological Exposition of the Holy Scripture, New American Commentary 27, Broadman Press, Nashville 1995.

Oppenheim A.L., Ancient Mesopotamia: Portrait of a Dead Civilization, University of Chicago Press, Chicago - London 1977.

Paciorek A., Ewangelia według świętego Mateusza. Wstęp - przekład z oryginału - komentarz, Nowy Komentarz Biblijny: Nowy Testament, t. I/1, Edycja Świętego Pawła, Częstochowa 2008.

Propp W.H.C., Exodus 19-40. A New Translation with Introduction and Commentary, The Anchor Bible 2A, Doubleday, New York i in. 2006.

Reuter E., Kultzentralisation: Entstehung und Theologie von Dtn 12, Athenäums Monografien, Bonner Biblische Beiträge 87, Anton Hain, Bonn 1993.

Sasson J.M., Theologies, Priests and Worship in Ancient Mesopotamia, w: Civilizations of the Ancient Near East, t. 1, J.M. Sasson (red.), Charles Scribner’s Sons, New York 1995.

Stanek T., Jahwe a bogowie ludów. Idee religijne wczesnego Izraela na tle wierzeń ludów Egiptu, Mezopotamii i Kanaanu, Biblioteka Pomocy Naukowych 23, Redakcja Wydawnictw Wydziału Teologicznego UAM, Poznań 2002.

Stein R.H., Luke. An Exegetical and Theological Exposition of Holy Scripture, New American Commentary 24, Broadman Press, Nashville 1992.

Stuart D., Hosea - Jonah, Word Biblical Commentary 31, Word Books Publisher, Dallas 1987. 
Stuart D.K., Exodus. An Exegetical and Theological Exposition of Holy Scripture, New American Commentary 2, Broadman Press, Nashville 2006.

Swartley W.M. (red.), The Love of Enemy and Nonretaliation in the New Testament, Westminster/John Knox Press, Louisville 1992.

Toorn van der K., The iconic Book: Analogies between the Babylonian Cult of images and the Veneration of the Torah, w: The Image and the Book: Iconic Cults, Aniconism, and the Rise of Book Religion in Israel and the Ancient near East, K. ven der Toorn (red.), Peeters, Leuven 1997.

Walker C., Dick M.B., The Induction of the Cult Image in Ancient Mesopotamia: The Mesopotamian mrs pi Ritual, w: Born in Heaven, Made on Earth: The Making of the Cult Image in the Ancient Near Eeast, M.B. Dick (red.), Eisenbrauns, Winona Lake 1999. 